International Journal of Linguistics, Literature and Culture
Available online at https://sloap.org/journals/index.php/ijllc/
Vol. 5, No. 5, September 2019, pages: 23 29
$\begin{aligned} & \text { ISSN: 2455-8028 } \\ & \text { https://doi.org/10.21744/ijllc.v5n5.736 }\end{aligned}$

\title{
Character Education through Diksha Suputra on Ambar Asram
}

\author{
I Gede Putu Yasa ${ }^{a}$ \\ Ida Ayu Gde Yadnyawati ${ }^{b}$ \\ I Wayan Budi Utama ${ }^{c}$
}

\section{Article history:}

Received: 09 March 2019

Accepted: 31 July 2019

Published: 06 September 2019

\section{Keywords:}

ambar ashram;

character;

community;

diksha suputra;

education;

\section{Author correspondence:}

I Gede Putu Yasa,

Universitas Hindu Indonesia, Denpasar, Indonesia.

Email address: yasaigedeputu@gmail.com

\begin{abstract}
The current study was intended at determining the reasons for character education through diksha suputra. It was implanted on ambar ashram. It was to describe the process of character education. The last one was to elaborate on the implications of character education through diksha suputra for students, family, and community. The present research was field research. The qualitative research was applied on analyzing the data. Data collection was conducted based on observation, in-depth interviewed, and document study. Data analysis was performed with interpretative descriptive techniques. The theory was used namely structural-functional theory, social learning theory, and essentialism theory.
\end{abstract}

2455-8028 ${ }^{\circledR}$ Copyright 2019. The Author. This is an open-access article under the CC BY-SA license (https://creativecommons.org/licenses/by-sa/4.0/) All rights reserved.

\section{Introduction}

The nation existence is very determined on the strength of nation's character. Therefore, it becomes very important on maintaining nation existence in the midst of world association. They inevitably have to be recognized. There will always be mutual influence among nations. The global era cultural communication intensity is fast. If the nation without strong character provision will certainly not be able to withstand. The swift currents are to change and hit the current world (Maba et al., 2017; 2018).

Character education through formal and informal education is believed to be an important way of building the next generation character. One form of character education conducted at Ambar Ashram becomes very interesting to be observed. It is to consider on the education process. It uses a religious approach.

Andrie Wongso (2007), stated that human character can be changed and shaped through ways. They are included having good ideals, always and getting used to thinking, the best saying and doing, passionate, persevering, resilient,

\footnotetext{
a Universitas Hindu Indonesia, Denpasar, Indonesia

${ }^{\mathrm{b}}$ Universitas Hindu Indonesia, Denpasar, Indonesia

${ }^{\mathrm{c}}$ Universitas Hindu Indonesia, Denpasar, Indonesia
} 
patient, ready and brave to change, ready to accept challenges, always give thanks and pray for everything to God. Therefore, the character can be changed on getting used to always think, say, and do the best. Likewise, Ambar Ashram students are always taught and obliged to familiarize themselves at all times through life based on truth teachings. Thus, the student's existence on ashram and after being on community always emulate goodness and help people for teachings of the selfless truth, full tolerance, grateful always, and loving. It is important amid changes on society. The religion function in society also experiences a shift away from its original function. Its presence is no longer monopolized on regional identity (Utama, 2018).

Ambar Ashram is located in Ubud area. It is based on Hinduism. The uniqueness is to apply yoga through the concept of "laughter" essentially develops and harmonizes the chakras in the body feel happy. Therefore, the development process has naturally occurred without coercion. Laughing according to the founder is a person in ashram charge. Kadek Suambara stated, it is not just laughing, but also letters combination has the power to stimulate chakras development in the human body. Ashram on forming the character, especially, children who are in brahmacari level. The concept used is "Diksha Suputra" defines the diksha energy distribution regarded as the concept of balance and harmony. Therefore, children become more focused on everything. Everyone knows almost all religions including Hinduism belong in the human is the God's creatures, the most perfect than any other living creature on earth (Rahmawati et al., 2018; Suastra, 2017).

Humans have Tri Pramana. They are bayu (energy), sabda (voice), and idep (mind). Animals only have bayu and sabda. Even more, plants only have bayu. Humans are given having the mind to distinguish what is good and what is bad, what is right, and what is wrong, and are given the mind to make a better life. Humans are God's representatives in the world. Due to human beings can make nature and life on earth for the better or even be destroyed. Therefore, human character is very necessary and urgent to improve life on earth to be better. Regarding a good character can change their self, surrounding environment, and wider community for the better through a loving attitude, helping each other with sincerity, and always practice the true teachings in daily life.

\section{Materials and Methods}

The present research was field research. The qualitative research was applied on analyzing the data. Data collection was conducted based on observation, in-depth interviewed, and document study. Data analysis was performed with interpretative descriptive techniques. The theory was used namely structural-functional theory, social learning theory, and essentialism theory.

Ambar Ashram is located in Banjar Nyuh Kuning. It is located in Ubud sub district, Gianyar regency, precisely in Mas Village area. Ubud subdistrict generally has an area about $42.38 \mathrm{~km}^{2}$. It is divided into eight villages namely; Singakerta, Lod Tunduh, Mas, Peliatan, Petulu, Ubud, Sayan, dan Kedewatan. The population is about 78000 inhabitants. Mas Village consists of four traditional villages and 12 banjar dinas. The population is about 12,000 inhabitants on $4.65 \mathrm{~km}^{2}$ area. Mas Village is a village that is rich in artistic, cultural, ecological, and religious potential. Wherein, $30 \%$ population is to work on the home arts industry craft. Banjar Nyuh Kuning is an area in Mas Village, Ubud. If it is seen from its uniqueness. It is included a region that is quite unique and very religious. It is religious due to the end banjar, there is a monkey tourism forest. It was known as the mongkey forest.

Ambar Ashram is generally better known on the surrounding community as a healing and self-awareness center. There was pioneered by Made Suambara in 1995. He is arguably a modern Balinese spiritual practitioner who was born in Banjar Nyuh Kuning, Mas, Ubud, Gianyar. He learned yoga, meditation, and spirituality from world-class masters. Ambar Ashram has temple that serves to worship the greatness of the God in the statue form, the manifestation of Lord Shiva with Parvati, Vishnu with Laksmi and Lord Brahma with Saraswati. There is also a worship statue on various beliefs. Ambar Ashram offers four main programs: healthy without drugs, diksha suputra, tapa yoga semadhi, and laksmi puja.

\section{Results and Discussions}

The important value on character education is optimizing the contents of good and positive character (character, attitude, the behavior of nobility, and noble character). It becomes a strong grip and the basic capital for the development of individuals and the nation later. The western world has long since realized how science without character becomes meaningless. Goleman (2008), stated that how human personality dominates $80 \%$ life person, 
compared with $20 \%$ their brain's intelligence own. The technocrats in the western world are aware that no matter how much progress is made. It can be destructive if it is not equipped with character balancing which combines ethical, moral, and religious principles. Therefore, education is currently conducted for the Indonesian people must be able to contribute to the formation of the nation's character. It will be easier if the character's learning is revitalized through education.

Wibowo (2013), stated there are 11 principles in order to the character education can effectively run: (1) consider the core ethical and supporting performance values as good character foundation, (2) define comprehensively character is included thoughts, feelings, and behavior, (3) use a comprehensive, deliberate, and proactive approach to character development, (4) create a caring school community, (5) give students the opportunity to take moral action, (6) create an academic curriculum that meaningful and challenging respected all students develop character, help students to succeed, (7) try to encourage student self-motivation, (8) involve school staff as a learning and moral community who share responsibilities on character education and efforts to adhere to the same core value guides student education, (9) fostering togetherness on moral and dual leadership long-term support for character education initiatives, (10) involve families and community members as partners on character building efforts, (11) evaluation of school characters, the school staff function as character educators, and the extent to which students manifest themselves.

It is important on the character education to develop core ethical values unlike caring, honesty, fairness, responsibility, and respect for self (Suarta, 2017). Supporting performance values unlike perseverance, high work ethic, and persistence as a basis for character good to follow education. There are several stages on ambar ashram that must be passed, namely as follows.

First, the registrant's number had been at least 30 people were gathered, then, looking for the day determination that was considered good according to the provisions. It was according to Hinduism, was considered dewasa ayu (good day) for diksha ceremony. It was separated between days for elementary school children towards middle and high school children. The basic material is the same but for those who are already junior, high school, and youth. There is a little extra and the explanation for each component more complete.

Secondly, they are required to include their parents on diksha process. They will be given some understanding of the diksha meaning. Some processes will be conducted by their parents.

Third, the specified day and date, as well as the time, was explained, when they registered. It then starts on giving a separate explanation between the collected parents on a certain location and the child at another location. However, it is still on ashram environment. The parents explained that each human being has their destiny and talents according to their karma. They here are expected to understand the talents of their children. Humans are generally divided into four groups: religious, statesmen, entrepreneurs, and workers. It id defined after being explored and known the child's talent. The parents should no longer force their will on the child's talent or profession. It is also explained the purpose of diksha is to make children happy and successful. Thus, looking success is happiness. The successful people are not sure be happy, but happy people are likely to achieve success.

The parents often bicker to their children, could be an uncomfortable relationship. Due to they often underestimate and consider their children stupid. Vice versa, the child considers their parents are old thinking. It is here hope harmony, mutual understanding, and mutual acceptance are expected. Due to understanding and accepting each other can create harmony between parents and children. Therefore, it is to keep in mind harmony is the true happiness basis.

Fourth, after explaining the purpose of diksha, the purpose of life begins with happiness by standing and learning to laugh without feeling ashamed or laughing made up. All participants position here is the same. They want to be happy first, thus, everyone starts doing yoga laughing. The happy people laugh for sure, and people laugh happily are truly happy people. All participants, parents, and children are invited to laugh sincerely first, then they truly feel truly happy.

Fifth, after laughing yoga session about 3-5 minutes, already feels fresh and happy is continued to see videos of children meditating in India with funny conditions unlike, drowsiness. It provokes a cheerful atmosphere. The screen came out texting Diksha Suputra. It is described the purpose of diksha suputra. It is to form children to be successful and happy, the explanation of success and happiness at all times by humans, the process of noetic by God through prayer. Without God interfering with, humans cannot do anything. There is also explained the God unlike Tri Murti, namely Brahma, Vishnu, and Ciwa, Catur Asrama wherein brahmacari on studying must worship the Lord of Ganesha and Saraswati. Lord Ganesha frees all obstacles and Goddess Saraswati blesses the intelligence and the master of science both worldly and spiritual knowledge.

Yasa, I. G. P., Yadnyawati, I. A. G., \& Utama, I. W. B. (2019). Character education through diksha suputra on ambar asram. International Journal of Linguistics, Literature and Culture, 5(5), 23-29. https://doi.org/10.21744/ijllc.v5n5.736 
Sixth, it is explained about the life process and asked each child what his/her ideals are. Then, writing these ideals due to the ideals are something plays a role and important in life. It is explained that success can be through two ways namely, through learning and indeed because of birth. Therefore, the worship priority when diksha and daily life at home. After diksha, it is to worship and singing or mantram, ganesha puja, hyang widhi puja, and saraswati puja, who have been given text on registration along with its prayer beads.

The diksha suputra process conducted by children in ambar ashram, Mas Village, Ubud has a direct impact on the child's character. Respecting diksha suputra, the ashram formed the child character and mentality become a suputra (good child).

The benchmarks is used in the current study seeing the diksha suputra process implications or influence are referring to the three Hinduism basic. They are tattwa/philosophy that is a belief in Panca Srada namely, how the belief affects on children about the existence of the God as universe creator. In this case, how children grow and strengthen their beliefs wherein, whenin, brahmacari group always worship God in the form of Goddess Saraswati. It is believed to guide both thoughts, words, and deeds to be better. The Goddess will also bless them with the intelligence and knowledge they need. They can achieve success and happiness.

The diksha suputra procession is related to the basic framework of Hinduism. The basic frameworks are conducted with confidence and sincerity. It is conducted with love and harmonious cooperation between the parents and the child. Therefore, the diksha procession can run in a solemn atmosphere.

\section{Conclusion}

Some point can be concluded. First, there are two considerations underlie the importance of character education through diksha suputra. They are ideological considerations and practical considerations. The character education ideologically is a systemic and structured effort undertaken to instill values. It will guide the lives of young people in the future. It is based on religious concepts as guidelines for behavior. The action practically is a habit, therefore, the pasraman participants are accustomed to self-discipline early on. They will become habitus to act nobly in the future.

Secondly, diksha suputra ceremony is basically conducted provides a strong foundation for the younger generation. They are better able to adjust to the changing times. Wherein, the intercourse and communication will occur. Questioning about character education is an effort. A religion can only be understood on looking at the social role. It plays in uniting communities. The religious education must be able to unify the functional community. It will be achieved if there is a growing awareness that religion is an autonomous cultural phenomenon. They cannot be reduced to the extent of economic interests and political demands in a multi-cultural society.

Third, the character education implication on diksha suputra ceremony for the children of pasraman participants is the building of self-confidence. There is instilled through the doctrines as humans. It must be diligent on learning, not to be lazy, especially, learning and helping parents. It is diligently to learn to fight the main enemy, it is ignorance. Ignorance is the causes of anxiety, worry, and fear, and ignorance raises doubts in dealing with every problem. The ignorance results in failure are sadness and being angry. The sadness and failure will foster jealousy and envy or hate to successful people. Therefore, the first thing conducted is to fight ignorance through focused, diligent, and tenacious learning. Thus, someone becomes successful and happy.

The activity also has implications for the family and environment. If there are good and positive habits have become someone's daily patterns, they will feel attached and feel something is lacking in life. If they have not done it. The formation of children's character through diksha suputra has implications for the family. They are very happy when there is a change in the character of their children. It shows that diksha suputra implementation is very good for the religious value inculcation.

Every community, wherever, they are must have their own characteristics as a norm in the socio-cultural field. It is different from other communities. The norms on society must be followed by their citizens. The norms influence the formation of their citizen's personalities on acting and behaving. There are the rules passed on the older generation to the next generation. Transmission is conducted consciously and aims. It is the process and education role in society.

This research theoretically also found. First, the character development must be conducted structurally and systemically from an early age, starting in the family, school, and community environment. Character education through the process of habituation through joint activities under the guidance of teachers, trainers, people who are emulated functional in building children's character. 
Second, the learning process views human behavior is not merely an automatic reflex of stimulus and response. But it is also due to reactions arising as a result of interactions between the environment and human cognitive schemes itself. It may still be relevant in relation to diksha suputra process.

It is recommended to decision-makers on education field that character education is very important given to students. The given education becomes an important foundation on the student's development in the future. It is suggested to the family that character education can be early conducted on the family by instilling the values of kindness and honesty, making a good source of good family growth, and children development for the next generation. All parties cooperation is certainly very necessary. Therefore, there is no gap between the value system. It is embedded in the family and the school. It is faced with the situation and conditions that develop in the community.

\section{Conflict of interest statement}

The authors declared that they have no competing interest.

\section{Statement of authorship}

The authors have a responsibility for the conception and design of the study. The authors have approved the final article.

\section{Acknowledgments}

The authors would like to thank the editor of IJLLC for their valuable time, support, and advice on completing the current study. 


\section{References}

Goleman, D. (2008). Destructive emotions: A scientific dialogue with the Dalai Lama. Bantam.

Maba, W. (2017). The implementation of education national standard in the instrument of school accreditation of Bali province education authority. International Research Journal of Engineering, IT \& Scientific Research, 3(4), $1-7$.

Maba, W., Perdata, I. B. K., \& Astawa, I. N. (2017). Constructing assessment instrument models for teacher's performance, welfare and education quality. International Journal of Social Sciences and Humanities, 1(3), 8896. https://doi.org/10.29332/ijssh.v1n3.59

Maba, W., Perdata, I. B. K., Astawa, I. N., \& Mantra, I. B. N. (2018). Conducting assessment instrument models for teacher competence, teacher welfare as an effort to enhance education quality. International Research Journal of Management, IT and Social Sciences, 5(3), 46-52.

Rahmawati, N. N., Kumbara, A., \& Suda, I. K. (2018). Multiculturalism towards religious life in tewang tampang village: moral education implementation based local wisdom. International Journal of Linguistics, Literature and Culture, 4(6), 63-71. https://doi.org/10.21744/ijllc.v4n6.408

Suarta, I. M. (2017). Revitalization of oral literature tradition of Balinese society based character values as deradicalism effort. International Journal of Social Sciences and Humanities, 1(3), 8-16. https://doi.org/10.29332/ijssh.v1n3.48

Suastra, I. W. (2017). Balinese local wisdom and their implications in science education at school. International Research Journal of Management, IT and Social Sciences, 4(2), 48-57.

Utama, I. W. B., \& Paramita, I. G. A. (2018). agama Dan Fenomena kegilaan. Vidya Wertta: Media Komunikasi Universitas Hindu Indonesia, 1(1), 107-113.

Wibowo, A. (2013). Pendidikan Karakter Berbasis Sastra, cet. ke-1. Yogyakarta: Pustaka Pelajar.

Wongso, A. (20). Wisdom and Success Classical MotivationStories 4. Jakarta: AW Publishing. 
Biography of Authors

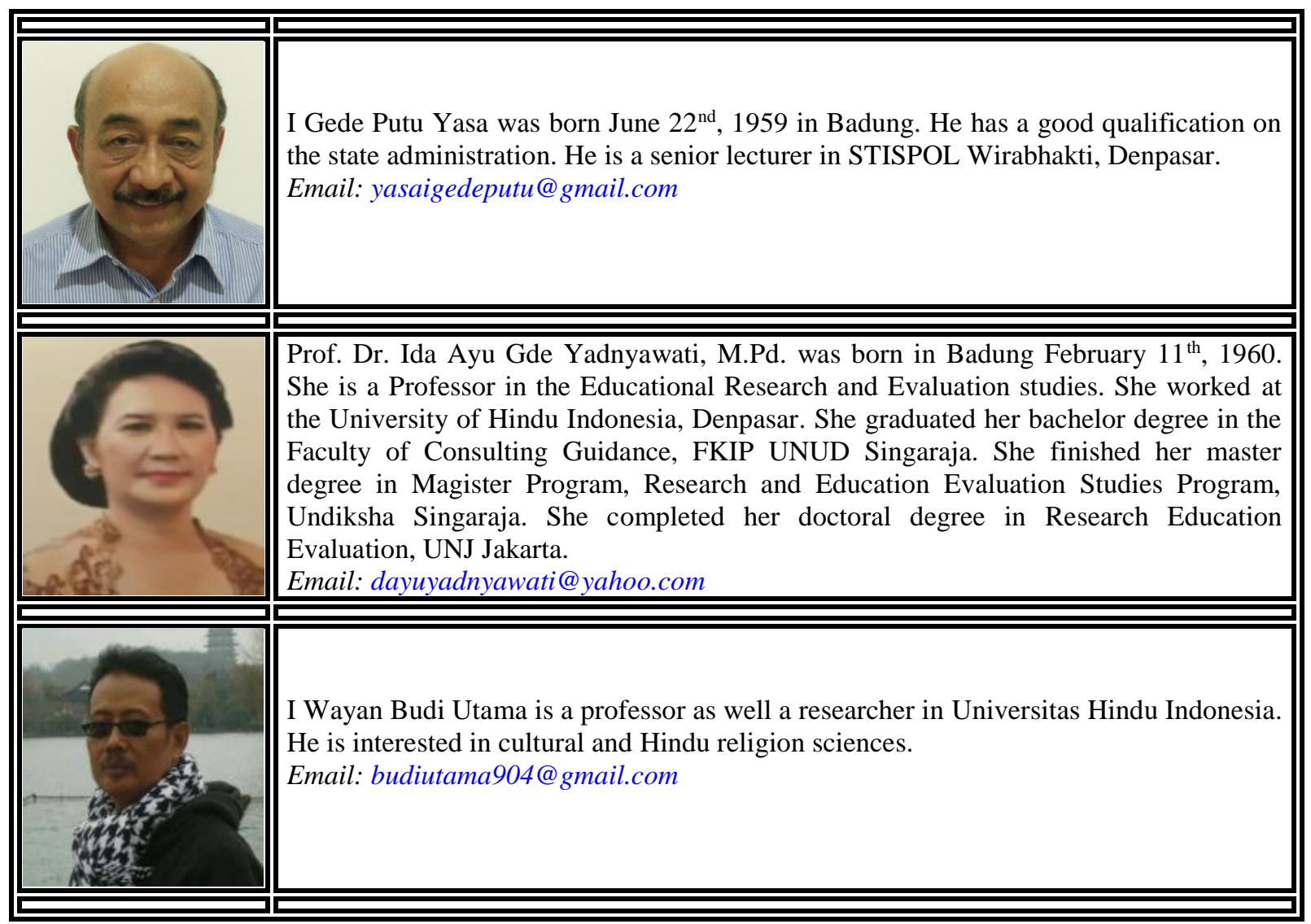

Yasa, I. G. P., Yadnyawati, I. A. G., \& Utama, I. W. B. (2019). Character education through diksha suputra on ambar asram. International Journal of Linguistics, Literature and Culture, 5(5), 23-29. https://doi.org/10.21744/ijllc.v5n5.736 